\title{
ANALISIS PENGGUNAAN METODE EKSPERIMEN TERHADAP KEMAMPUAN MENGENAL WARNA PADA ANAK USIA DINI
}

\author{
Alvan Hazhari' ${ }^{1}$, Marini Magdalena ${ }^{2}$, arsih $^{3}$ \\ ${ }^{1}$ Sekolah Tinggi Keguruan dan Ilmu Pendidikan Banten \\ ${ }^{2}$ Sekolah Tinggi Keguruan dan Ilmu Pendidikan Banten \\ ${ }^{3}$ Mahasiswa Pendidikan Guru Pendidikan Anak Usia Dini \\ Penulis Korespondensi : hazharialvan2193@gmail.com ${ }^{1}$,rini_magda@yahoo.com², \\ warsihrajeg@gmail.com ${ }^{3}$

\begin{abstract}
The problem of this study is how to analyze the use of experimental methods on the ability to recognize color in early childhood? The purpose of this study is to find out the analysis of the use of experimental methods in the ability to recognize color in early childhood. The research that researchers do is in the form of literature studies consisting of primary sources and secondary sources. The results of the study from data that have been analyzed by researchers from each study there is a difference in the percentage of ability to know in early childhood. The conclusion that the analysis of the use of experimental methods on the ability to recognize color in early childhood has increased.
\end{abstract}

Keywords: Experimental Method, Ability to Know Color

\begin{abstract}
ABSTRAK
Permasalahan penelitian ini adalah bagaimana analisis penggunaan metode eksperimen terhadapa kemampuan mengenal warna pada anak usia dini? Tujuan penelitian ini adalah untuk mengetahui analisis penggunaan metode eksperimen terdahap kemampuan mengenal warna pada anak usia dini. Penelitian yang peneliti lakukan ini berupa studi literatur yang terdiri dari sumber primer dan sumber sekunder. Hasil penelitian dari data yang sudah dianalisis oleh peneliti dari setiap penelitian adanya perbedaan peningkatan presentase kemampuan mengenal pada anak usia dini. Kesimpulan bahwa analisis penggunaan metode ekperimen terhadap kemampuan mengenal warna pada anak usia dini mengalami peningkatan.
\end{abstract}

Kata kunci: Metode Eksperimen, Kemampuan Mengenal Warna 


\section{PENDAHULUAN}

Pembangunan

Nasional

ditujukan untuk mewujudkan citacita kemerdekaan bangsa Indonesia khususnya dalam upaya mencerdaskan kehidupan bangsa, sehingga akan menjadi bangsa yang beradab dan dapat bersaing di dunia Internasional. Untuk mewujudkan cita-cita tersebut perlu adanya pendidikan sejak dini saat anak masih kecil. Permendiknas 58 Tahun 2009 menyatakan bahwa pendidikan anak usia dini merupakan usia anak yang efektif untuk mengembangkan berbagai potensi dan keterampilan yang dimiliki anak, karena anak usia dini mengalami lompatan perkembangan otak mencapai $80 \%$, pada saat ini lah paling tepat untuk mengembangkan kemampuan anak di segala bidang.

Suyadi (2010) Undang-undang No.20 Tahun 2003 tentang Sistem Pendidikan Nasional menyatakan bahwa pendidikan anak usia dini adalah suatu upaya yang ditunjukan kepada anak sejak lahir sampai pada anak usia 6 tahun yang dilakukan melalui rangsangan pendidikan untuk membantu pertumbuhan dan perkembangan jasmani dan rohani agar anak memiliki kesiapan dalam memasuki pendidikan yang lebih lanjut.

Sehubungan dengan hal tersebut pendidikan anak usia dini membutuhkan peran serta lingkungan untuk mengoptimalkan pertumbuhan dan perkembangan anak, dalam rangka membangkitkan suasana belajar yang menarik dan menyenangkan sesuai dengan prinsip pendidikan prasekolah yaitu belajar sambil bermain dan bermain sambil belajar.

Kegiatan belajar di PAUD disusun untuk mencapai tujuan pendidikan nasional yang disesuaikan dengan lingkungan, kebutuhan-kebutuhan pembangunan nasional serta perkembangan dalam pengetahuan dan kreativitas anak. Aspek kognitif sebagai salah satu bidang pengembangan perkembangan dasar dalam kurikulum PAUD memegang peranan strategis dalam upaya mengembangkan perkembangan berpikir anak untuk dapat mengolah hasil belajarnya. 
Alvan Hazhari, Marini Magdalena, dan Warsih. Metode Eksperimen Terhadap Kemampuan Mengenal Warna Pada Anak Usia Dini

Tujuan pendidikan dan pembelajaran yang akan diterapkan kepada anak usia dini, termasuk dalam bidang pengembangan pembelajaran pengetahuan untuk anak. Pemahaman dan penguasaan akan tujuan dan ruang lingkup pendidikan pengetahuan akan banyak membantu pengajaran dalam program pembelajaran anak usia dini yang dianggap tepat. Telah diketahui bahwa pembelajaran ilmu pengetahuan tidak bisa lepas dari kehidupan, pembelajaran pengetahuan sangat penting diterapkan pada anak usia dini karena ilmu pengetahuan akan membahas tentang masalah yang ada disekitar kita.

Melalui pembelajaran ilmu pengetahuan anak akan dapat mengetahui mengapa terjadi malam, mengapa air bisa mendidih, mengapa ada hujan dan lain-lain. Guru memberikan pelajaran sains yang mudah dan dekat dengan lingkungan anak. Melalui pembelajaran ilmu pengetahuan anak akan bisa menjawab bagaimana jika daun berwarna hijau, jika api berwarna merah dan hal hal lainnya.
Berdasarkan analisis yang sudah dilakukan peneliti, dari jurnal dan skripsi terdahulu yang relevan, bahwa Peneliti melihat pada saat pembelajaran tentang kemampuan mengenal warna, terlihat bahwa masih banyak anak yang belum mampu mengenal warna dengan tepat. Pada saat guru melakukan proses pembelajaran, guru memberi perintah anak untuk menunjukan warna, seperti saat guru meminta anak untuk menunjukan warna kuning, anak masih menunjukan 2 warna yang berbeda yaitu warna kuning kemudian berganti menunjukan warna orange.

$$
\text { Pada kemampuan }
$$

menyebutkan warna, anak belum mampu membedakan warna merah dengan orange, kuning dengan orange, hijau dengan biru, biru dengan ungu. Hal tersebut disebabkan karena anak kurang memiliki kemampuan mengenal warna, media yang dilakukan kurang menarik dalam pembelajaran, metode yang digunakan belum optimal dalam kemampuan mengenal warna, metode eksperimen terhadap kemampuan 
warna anak usia dini belum dilakukan.

Metode

pembelajaran merupakan salah satu komponen penting yang mempengaruhi berlangsungnya kegiatan pembelajaran. Adanya unsur lingkungan anak membuat kegiatan pembelajaran di sekolah kini juga disampaikan dengan menggunakan berbagai metode pembelajran yang mengkaitkan antara materi yang dipelajari anak di sekolah dengan lingkungan atau pengalaman yang dialami anak dilingkungan sekitarnya. Penggunaan berbagai metode pembelajaran diharapkan akan membuat anak dapat lebih memahami materi yang diterimanya di sekolah dan mampu mengaplikasikannya dalam dunia nyata anak.

Dari permasalah yang telah dipaparkan di atas,di perlukan suatu upaya untuk dapat menemukan cara yang tepat berkenaan dengan kemampuan mengenal warna anak usia dini. Salah satu cara dalam mengenalkan warna pada anak usia dini adalah dengan memberikan metode yang menyenangkan bagi anak, yaitu dengan menggunakan metode eksperimen. Karena dengan metode eksperimen anak terlibat langsung dalam melakukan suatu percobaan sehingga anak tertarik untuk melakukan kegiatan proses pembelajaran.

Dari uraian diatas dapat ditarik kesimpulan bahwa metode eksperimen adalah salah satu cara mengajar dimana anak mengalami dan melakukan sendiri mengenai suatu proses kejadian dan kemudian menarik kesimpulan dari suatu percobaan yang mereka lakukan.

Berdasarkan pernyataan diatas maka tujuan pada penelitian ini adalah sebagai berikut: Untuk mengetahui, analisis penggunaan metode eksperimen terhadap kemampuan mengenal warna pada anak usia dini.

\section{LANDASAN TEORI}

\section{Metode Eksperimen}

Dewi (2016) menyatakan bahwa metode ekperimen (percobaan) adalah penyajian pembelajaran dimana siswa melakukan percobaan dengan mengalami dan membuktikan sendiri sesuatu yang dipelajari. 
Alvan Hazhari, Marini Magdalena, dan Warsih. Metode Eksperimen Terhadap Kemampuan Mengenal Warna Pada Anak Usia Dini

Dalam proses belajar mengajar dengan metode percobaan ini siswa diberi kesempatan untuk mengalami suatu objek, menganalisis, membuktikan dan menarik kesimpulan mengenai suatu objek, keadaan, atau proses sesuatu. Siswa diberi kesempatan untuk menyusun konsep-konsep dalam stuktur kognitifnya selanjutnya dapat diaplikasikan di kehidupan.

Gunarti winda (2012) metode eksperimen atau percobaan adalah suatu kegiatan yang didalamnya dilakukan percobaan dengan cara mengamati proses dan hasil dari percobaan tersebut.

Istiyati (2014) menyatakan bahwa metode eksperimen adalah cara pembelajaran yang melibatkan anak dengan mengalami dan membuktikan sendiri proses dan hasil percobaan. Melalui metode eksperimen cara penyajian bahan pelajaran yang melibatkan guru dan peserta didik melakukan percobaan dan mengamati proses dan hasil percobaan.

Rachmawati (2010) metode eksperimen (percobaan sederhana) yang dimaksud dalam hal ini bukanlah suatu proses rumit yang harus dikuasai anak sebagai suatu cara untuk memahami konsep dasar eksperimen, melainkan bagamana mereka dapat mengetahui cara atau proses terjadinya sesuatu, mengapa sesuatu dapat terjadi, serta bagaimana mereka dapat menemukan solusi terhadap permasalah yang ada dan pada akhirnya mereka dapat membuat sesuatu yang bermanfaat dalam kegiatan tersebut.

Melalui ekperimen anak berlatih mengembangkan kreativitas, kemampuan berpikir logis, senang mengamati, meningkatkan rasa ingin tahu dan kekaguman pada alam, ilmu pengetahuan dan Tuhan. Melalui eksperimen sederhana anak akan menemukan hal ajaib dan menakjubkan.

Siti mardhiyah (2014) juga menyatakan bahwa pembelajaran dengan metode eksperimen akan berdampak pada seluruh aspek-aspek perkembangan adalah sebagai berikut:

- Aspek intelektual

Kegiatan eksperimen dapat memuaskan rasa ingin tahu anak, 
membangun kemampuan berpikir logis, kritis, analisis, dan sintesis.

- Bahasa

Kegiatan eksperimen akan mendorong anak untuk mengkomunikasikan ide dan pikirannya serta menguraikan hasil temuannya.

- Fisik Motorik

Kegiatan eksperimen motorik anak dapat dikembangkan terutama motorik halus, kegiatan ini akan terlibat dalam kegiatan menuang, memegang, mencampur, dan mengaduk.

- Seni

Kegiatan eksperimen anak dapat menghasilkan nada yang berbeda dengan berbagai macam benda, pencampuran warna dengan melukis, dan menari sesuai dengan irama yang didengar.

- Sosial Emosional

Kegiatan eksperimen terdapat kerja sama antara individu untuk menghasilkan sesuatu.

- Moral Agama

Kegiatan eksperimen, terdapat nilai-nilai religius berupa kebesaran ciptaan Tuhan.

\section{Kelebihan dan Kekurangan}

\section{Metode Eksperimen}

Kelebihan dan kekurangan metode eksperimen (percobaan sederhana) menurut Gunarti Winda (2012) adalah sebagai berikut:

\section{Kelebihan metode eksperimen}

Metode ini dapat membuat anak didik lebih percaya atas kebenaran atau kesimpulan berdasarkan percobaannya sendiri dari pada hanya menerima penjelasan yang disampaikan pendidik atau dari dalam buku.

Anak didik dapat lebih mengembangkan sikap dan menyalurkan rasa ingin tahunya untuk mengadakan studi eksplorasi (menjelajahi).

Melalui metode ini akan terbina manusia yang dapat mengembangkan inovasi baru dengan penemuan hasil percobaan dan diharapkan dapat bermanfaat bagi kesejahteraan hidup manusia.

Metode ini menerapkan prinsip learning by experiencing (belajar dari pengalaman) dalam belajar anak. Melalui eksperimen anak didik dapat mengalami langsung maupun 
Alvan Hazhari, Marini Magdalena, dan Warsih. Metode Eksperimen Terhadap Kemampuan Mengenal Warna Pada Anak Usia Dini

tidak langsung suatu peristiwa sebagai pengalaman belajar tertentu sehingga melalui pengalaman tersebut anak dapat mengidentifikasi gejala secara menyeluruh.

Metode ini dapat menumbuhkan kepercayaan diri anak didik terhadap masalah yang akan dipecahkannya. Anak didik berusaha menjelajah lingkungan yang menjadi objek penelitiannya hingga dia dapat memetik hasil dari dan akan menumbuhkan rasa percaya diri dan keyakinan.

\section{Kekurangan metode eksperimen}

Jika eksperimen memerlukan proses hasil dengan jangka waktu yang lama. Proses eksperimen yang kadang berlangsung lama membuat anak harus menunggu. Hal ini akan menimbulkan kebosanan atau bahkan dapat mengurangi minat rasa ingin tahunya.

Kebanyakan metode ini hanya cocok untuk konsep sains/ilmu alam dan teknologi.

Metode ini memerlukan alat, fasilitas dan bahan yang lengkap sehingga jika salah satu alatnya kurang maka eksperimen akan berjalan kurang baik atau bahkan (c) 2021, JoEE, Jurnal of Early Childhood. PGPAUD e-ISSN: $2775-7870$ gagal.

Faktor keselamatan kerja perlu diperhitungkan dengan matang terutama pada eksperimen yang menggunakan cairan kimia.

Dari uraian di atas dapat disimpulkan bahwa kelebihan dari metode percobaan sederhana yaitu anak lebih yakin atas hasil yang mereka peroleh sehingga anak dapat menciptakan sesuatu yang baru dan juga mereka dapat mengaplikasikan penemuan mereka di dalam kehidupan sehari-hari. Sedangkan kekurangan dari metode percobaan sederhana yaitu antara lain tidak dapat diterapkan pada semua bidang ilmu dan juga memerlukan alat dan bahan yang mahal dan bahkan terkadang susah didapat dan juga setiap melakukan percobaan sederhana hasilnya tidak selalu berhasil sesuai dengan yang kita harapkan.

\section{Kemampuan Mengenal Warna}

\section{A. Pengertian kemampuan mengenal warna}

$\begin{array}{lr}\text { Menurut } & \text { Robbins } \\ \text { kemampuan adalah } & \text { kapasitas } \\ \text { individu melaksanakan } & \text { berbagai } \\ \text { tugas dalam suatu pekerjaan. }\end{array}$


Berdasarkan pendapat tersebut, kemampuan mengenal warna adalah kesanggupan anak dalam mengetahui warna dengan cara menunjuk, menyebut, dan mengelompokan warna yang di maksud guru melalui kegiatankegiatan pengenalan warna.

Menurut Suratno mengenal warna merupakan salah satu indikator sains termasuk kedalam bidang pengembangan kognitif. Mengenalkan warna kepada anak dapat membentuk struktur kognitif dalam proses pembelajaran anak, anak memperoleh informasi yang lebih banyak sehingga pengetahuan dan pemahamannya akan lebih kaya dan lebih dalam. Dalam hal ini anak mengetahui warna secara konsep berdasarkan pengalaman belajarnya.

\section{B. Pengertian Warna}

Menurut

Departemen

Pendidikan Nasional (2005) Warna adalah unsur pertama yang terlihat oleh mata dari suatu benda. Menurut Depdiknas warna adalah kesan yang diperoleh mata dari cahaya yang di pantulkan oleh benda-benda yang dikenainya.
Unsur penting dari warna adalah objek (benda) yang kemudian diterima oleh mata karena adanya pantulan dari cahaya yang mengenai benda. Dengan demikian secara umum, warna didefinisikan sebagai unsur cahaya yang dipantulkan oleh sebuah benda dan selanjutnya diintrepetasikan oleh kerja otak mata berdasarkan cahaya yang mengenai benda.

Selain warna tersebut menurut penelitian warna dasar atau warna primer yang ada didunia ini ada tiga, yaitu merah, kuning, dan biru. Dari

ketiga warna ini bila dicampur akan menghasilkan semua warna lain senada dengan pendapat tersebut.

Menurut Gerret (2009) "warna pada prinsipnya hanya terdiri dari tiga warna yaitu merah, kuning dan biru. Sementara warna diluar ketiga tersebut merupakan gabungan dari ketiga warna itu.

\section{METODE PENELITIAN}

Metode penelitian yang digunakan dalam penelitian ini adalah penelitian kualitatif. Sedang jenis penelitian ini peneliti menggunakan studi literatur 
Alvan Hazhari, Marini Magdalena, dan Warsih. Metode Eksperimen Terhadap Kemampuan Mengenal Warna Pada Anak Usia Dini

yaitu mengumpulkan data atau karya HASIL PENELITIAN DAN
PEMBAHASAN tulis ilmiah yang berkaitan dengan objek penelitian atau pengumpulan data yang bersifat kepustakaan, atau telaah yang dilaksanakan untuk memecahkan masalah yang pada dasarnya tertumpu pada penelaahan kritis dan mendalam terhadap bahanbahan pustaka yang relevan.

Menurut Suarifqi Diantama (2018) studi literatur dilakukan dengan cara mempelajari dan mengkaji buku-buku atau sumber informasi tentang masalah yang diteliti, teknik ini selain digunakan untuk melengkapi serta memperkuat hasil penelitian yang dilakukan, teknik ini dilakukan dengan cara mengumpulkan berbagai macam sumber dan literatur buku-buku yang berkaitan dengan masalah yang sedang diteliti.

Menurut Amir Hamzah (2019) secara metodologis kepustakaan tergolong dalam jenis penelitian kualitatif, yaitu prosedur penelitian yang menghasilkan data berupa ucapan atau tulisan dan prilaku orang-orang yang diamati dalam suatu konteks tertentu dan holistik.

\section{A. Hasil \\ Proses Penggunaan Metode \\ Eksperimen Dari Setiap Sumber}

1. Kode Data A1

Kegiatan yang dilakukan pada tahap observasi awal (pre test) mencakup 2 aspek yang dinilai dengan alat penilaian yang berupa lembar observas, aspek yang dimaksud yaitu anak diminta guru untuk menyebutkan warna primer (merah, kuning dan biru) dan mengelompokan berasarkan warna (merah, kuning dan biru) dengan menggunakan kertas origami. Hasil rata-rata kemampuan mengenal warna sebelum diberikan penerapan metode eksperimenberbahan alam yaitu 5,92.

Sedangkan pada observasi akhir (past test) setelah penerapan berbahan alam dilakukan anak diminta guru maju satu persatu untuk menyebut warna primer (merah kuning dan biru) setelah itu anak mengelompokan berdasarkan warna primer (merah, kuning dan biru). Hasil rata-rata kemampuan mengenal warna setelah diberikan penerapan 
metode eksperimen berbahan alam yaitu 7,58. Maka dapat ditarik kesimpulan bahwa metode eksperimen berbahan alam dapat meningkatkan kemampuan mengenal warna.

\section{Kode Data A2}

Kegiatan yang dilakukan sebelum melakukan penelitian tindak kelas, dilakukan praobservasi untuk melihat kemampuan mengenal warna pada setiap anak yaitu:

a) Guru memperlihatkan beberapa alat dan bahan yang akan digunakan untuk kegiatan eksperimen mrncampur warna.

b) Anak diberi tugas untuk melakukan pencampuran warna Setelah selesai anak diberi kesempatan untuk melakukan kegiatan lain yang baik mengelompokan sesuai warna primer maupun hasil pencampuran warna.

c) Guru selalu memberi motivasi agar ank semangat dan antusias dalam melakukan kegiatan.

Hasil yang diperoleh pada saat pratindakan adalah sebesar sebesar 13,85 sedangkan tindakan pada siklus I diperoleh nilai rata-rata yaitu 17, kemudian siklus II diperoleh nilai rata-ratanya mencapai 20,92 Sedangkan nilai peningkatan pratindakan ke siklus I adalah 11, 26\%, sedangkan siklusni ke siklus II adalah $14,01 \%$. Maka dapat ditarik kesimpulan bahwa metode eksperimen dapat meningkatkan kemampuan mengenal warna pada anak usia 4-5 tahun dilembaga BKB PAUD Seruni, Jakarta.

\section{Kode Data A3}

Proses yang dilakukan pembelajaran larutan pelangi dapat dilihat ditabel dibawah ini.

\begin{tabular}{|c|c|c|c|c|}
\hline No & $\begin{array}{l}\text { Lar } \\
\text { utan } \\
\text { Pela } \\
\text { ngi }\end{array}$ & pretest & postes & Gain \\
\hline 1. & $\begin{array}{l}\text { Hari } \\
\text { ke } 1\end{array}$ & $\begin{array}{l}35,71 \\
\%\end{array}$ & $\begin{array}{l}28,57 \\
\%\end{array}$ & $\begin{array}{l}7,14 \\
\%\end{array}$ \\
\hline 2. & $\begin{array}{l}\text { Hari } \\
\text { ke } 2\end{array}$ & $\begin{array}{l}28,57 \\
\%\end{array}$ & $\begin{array}{l}14,28 \\
\%\end{array}$ & $\begin{array}{l}14,29 \\
\%\end{array}$ \\
\hline 3. & $\begin{array}{l}\text { Hari } \\
\text { ke } 3\end{array}$ & $\begin{array}{l}42,28 \\
\%\end{array}$ & $\begin{array}{l}21,42 \\
\%\end{array}$ & $\begin{array}{l}20,86 \\
\%\end{array}$ \\
\hline
\end{tabular}

Dari data diatas diketahui bahwa hasil pretest dan posttest pada pengaruh penerapan metode 
Alvan Hazhari, Marini Magdalena, dan Warsih. Metode Eksperimen Terhadap Kemampuan Mengenal Warna Pada Anak Usia Dini

eksperimen terhadap kemampuan dalam mengenal warna pada anak usia 4-5 tahun di RA Plus Ja-alhaq kota Bengkulu, mengalami peningkatan setelah dilakukan pembuatan larutan pelangi.

\section{Kode Data A4}

Proses yang dilakukan dengan 3 treatment yaitu : Pada Treatment pertama metode eksperimen dengan media cat air, dalam indikator menyebutkan warna, mengelompokan warna, rata-rata seluruh seluruh peserta didik mendapkan nilai yang sama. Kemampuan mengenal warna mengalami peningkatan dari nilai sebelumnya.

Pada Treatment kedua metode eksperimen degan media bola warna, pserta didik sangat antusias mendengarkan penjelasan guru, pada idikator "anak mampu memberikan Contoh warna dalam kemampuan mengenal warna”, terjadi peningkatan dari data sebelumnya.

Treatment terakhir metode eksperimen dengan media bahan pewarna makanan (susu pelangi), dalam melakukan percobaan eksperiment mengalami peningkatan yang sangat signifikan dalam kemampuan mengenal warna di Kelas A.

Maka dapat ditarik kesimpulan bahwa kemampuan mengenal warna melalui metode eksperimen yang dilakuan dengan treatment 1,2,3 dapat menigkat.

\section{Kode Data A5}

Proses penelitian yang dilakukan dalam 2 minggu, dimana setiap minggu terdiri dari 3 kali pertemuan. Dalam pertemuan minggu pertama dilakukan tindakan dalam pembelajaran dan pada minggu ke dua dilakukan evaluasi dan penilaian dari hasil tindakan.

\section{B. Pembahasan}

Pada siklus I hasil rata-rata persentase sebesar $64.75 \%$. dan pada siklus II hasil rata-rata persentase sebesar $83.43 \%$. Maka dapat ditarik kesimpulan siklus I ke siklus II bahwa penerapan metode eksperimen dapat meningkatkan kemampuan mengenal warna pada kelompok A di Paud Pradnya Paramita. 


\begin{abstract}
Berdasarkan hasil analisis penelitian bahwa penggunaan metode eksperimen dapat meningkatkan kemampuan mengenal warna pada anak usia dini.

Melalui pembelajaran dengan metode eksperimen anak terlibat langsung dalam melakukan suatu percobaan sehingga anak tertarik untuk melakukan kegiatan proses pembelajaran.

Melalui metode eksperimen dapat lebih mengembangkan sikap dan menyalurkan bakat anak dan mengeksplornya.

Metode eksperimen dapat membuat anak lebih percaya diri dengan percobaannya sendiri dari pada hanya menerima penjelasan yang disampaikan pendidik atau dari dalam buku.
\end{abstract}

\section{KESIMPULAN DAN SARAN}

\section{A. Kesimpulan}

Berdasarkan uraian dari keseluruhan dari hasil penelitian yang sudah dilakukan peneliti dapat menyimpulkan bahwa: "Analisis penggunaan metode eksperimen dapat meningkatkan kemampuan mengenal warna pada anak usia dini.
Melalui pembelajaran dengan metode eksperimen anak terlibat langsung dalam melakukan suatu percobaan sehingga anak tertarik untuk melakukan kegiatan proses pembelajaran, dapat lebih mengembangkan sikap dan menyalurkan bakat anak dan mengeksplornya, dapat membuat anak lebih percaya diri dengan percobaannya sendiri dari pada hanya menerima penjelasan yang disampaikan pendidik atau dari dalam buku.

\section{B. Saran}

Berdasarkan penelitian yang telah dilakukan, maka dapat peneliti sarankan kepada pihak-pihak yang terkait diantaranya :

1) Bagi guru, disarankan guru diharapkan dapat lebih inovatif dan kreatif dalam memberikan metode eksperimen yang tepat bagi anak, memilih metode yang menyenangkan agar anak tidak merasa bosan dalam mengikuti pembelajaran.

2) Bagi sekolah, disarankan lebih memperhatikan kemampuan mengenal warna anak, diadakan 
Alvan Hazhari, Marini Magdalena, dan Warsih. Metode Eksperimen Terhadap Kemampuan Mengenal Warna Pada Anak Usia Dini

media yang tepat untuk melakukan metode eksperimen. Dengan adanya media yang tepat tersebut maka diharapkan dapat meningkatkan kemampuan anak dalam mengenal warna.

3) Bagi peneliti, diharapkan menjadi hasil penelitian ini sebagai referensi untuk melakukan penelitian yang kebih baik lagi dengan penggunaan metode eksperimen yang lebih menarik dalam meningkatkan kemampuan mengenal warna pada anak usia dini.

4) Bagi mahasiswa, sebagai acuan atau pedoman untuk mahasiswa dalam proses penyusunan tugas akhir.

\section{DAFTAR PUSTAKA}

Artikel Dapur Ilmiah. (9 juni 2009)

"Penelitian Literatur". http://dapurilmiahblogspot.com /penelitian-literatur.htm

Departemen Pendidikan Nasional. (2005). Kamus Besar Indonesia. Jakarta: Balai Pustaka. Hal 113

Dewi, dkk. (2016). Meningkatkan kemampuan Sains Melalui Penerapan Metode Eksperimen pada Kelompok A Tk Sandhy
Putra Singaraja. Jurnal Pendidikan Anak Usia Dini.4(2)

Diantama, Suarifqi. (2018). Metode Penelitian Pendidikan. Bandung: Pustaka Rahmat . Hal 34

Hamzah, Amir. (2019). Metode Penelitian Keputakaan Liberary Research. Malang: Literasi Nusantara. Hal 25

Herlina, H. (2012). Kemampuan Mengenal Warna Pada Anak Usia 4-5 tahun di Tk Segugus III Kecamatan Panjatan Kabupaten Kulon Progo. Jurusan Pendidikan Pra Sekolah Dasar Fakultas Ilmu Pendidikan, Universitas Negeri Yogyakarta.

Istiyati,dkk. (2014). Peningkatan Pemahaman Konsep Berat Ringan dengan Metode Eksperimen Pada Anak Kelompok B1 TK Pertiwi Pulo Sari Karanganyar Program Studi PG-PAUD, Universitas Sebelas Maret.

Mardhiyah, S. (2014). Upaya Meningkatkan Kemampuan Mengenal Warna Melalui Metode Eksperimen Kelompok A RA Tamanagung 3 Muntilan, ( Jurusan Pendidikan Guru Madrasah Ibtidaiyah dan Keguruan, Universitas Negeri Sunan Kalijaga Yogyakarta.

Murniati, D. (2014). Meningkatkan Kemampuan Mengenal Warna 
Melalui Metode Eksperimen pada Kelompok B di PAUD Haqiqi Kota Bengkulu. ( Program Sarjana Kependidikan Bagi Guru dalam Jabatan Fakultas Keguruan dan Ilmu Pendidikan, Universitas negeri Surabaya.

Nazir, M. (2003). Metode Penelitian Kualitatif. Jakarta: Ghalia Indonesia.

NU 247 Manba'ur Rohmah Sumber Kebomas Gresik. Jurnal PAUD Teratai. Volume 05 Nomor 02, 52-56

Rachmawati, Y. (2010). Strategi Pengembangan Kreativitas Pada Anak Usia Taman Kanak-kanak. Jakarta: Kencana.

Sugiyiono. (2008). Metode Penelitian Kualitatif dan $R \& D$. Alfabet. Bandung Suratno. (2013). Konsep Kemampuan Sumber Daya Manusia.Suyadi. (2010). Psikologi Belajar PAUD. Yogyakarta: Pedagogia, 29 